\title{
Contribuição de melhoria. Apanhado geral do decreto-lei n. 195, de 24-2-1967*.
}

\author{
Antônio Chaves \\ Catedrático de Direito Civil da Faculdade de \\ Direito da U.S.P.
}

\section{Retrospecto histórico. Definição, natureza, fundamento jurídico.}

São diferentes as datas que os autores pretendem fixar para precedentes bem caracterizados da atual contribuição de melhoria. Alberto Deodato foi ver, com Canam, o instituto delineado em 1.250, nas leis relativas às obras de reparação do dique de Romey.

Adolfo Giaguinto aponta um ato legislativo inglês de 1662 e dois decretos do Conselho de Luís XIV, de 1672 e de 1678, que impuseram a vários proprietários contribuir, em proporção às vantagens que delas retiravam, às despesas de alargamento das vias às quais faziam frente seus prédios.

José Geraldo Ataliba Nogueira invoca uma lei inglêsa de 1605, que se propunha facilitar a navegação pelo Rio Tâmisa, de Londres a Oxford, considerando ser "razoável, justo e equânime que aquêles que participam do benefício decorrente de obra pública, contribuam em proporção conveniente, ao custo de dita obra."

* Este trabalho reproduz a palestra proferida em data de 8 de novembro de 1967, nos auditórios da Procuradoria Judicial do Departamento Estadual de Estradas de Rodagem de São Paulo. 
Muito citada passagem em que Pisanelli encarece que o instituto não constitui violação do direito do proprietário onerado, mas ao invés evita que se verifique a grave injustiça de fazer com que outros proprietários concorram para a utilidade daquele, facilitando a realização das obras públicas.

No Brasil, a primeira manifestação positiva pode ser localizada no decreto 1.029, de 6-7-1905, do Distrito Federal, determinando, em matéria de calçamento, que metade do custo da pavimentação corre por conta dos proprietários confinantes.

Em S. Paulo a Câmara Municipal de Taquaritinga chegou a promulgar a lei n. 89 de 30-9-1921, também relativa a calçamento, que todavia foi revogada, antes que fôsse declarada sua inconstitucionalidade.

Sòmente a Constituição de 1934, que autorizou, no art. 124 , a cobrança da contribuição de melhoria uma vez provada a valorização do imóvel por motivos de obras públicas, proporcionou melhor oportunidade para o surto de novas leis, como a paulista n. 2.509, de 2-2-1936, que também tiveram vida efêmera por não ter a Carta Constitucional de 1937 enumerado expressamente a contribuição de melhoria entre os tributos.

A Constituição de 1946 prevendo-a no art. 30 e seu parágrafo único deu ensejo ao evento da Lei n. 854, de 10-10-1949, que vigorou durante vários anos.

0 art. 19 da Emenda Constitucional n. 18, de 1-12-1965 atribuíu à União, aos Estados, ao Distrito Federal e aos Municípios cobrar contribuição de melhoria para fazer face ao custo de obras públicas de que decorra valorização imobiliária.

A Constituição de 15-3-1967 deu à matéria todo o realce, mencionando no art. 17 que o sistema tributário nacional compõe-se de impostos, taxas e contribuições de melhoria, voltando a mencionar esta última novamente no art. 18, n. III e no seu $\S 3^{\circ}$. 
Finalmente, o decreto-Iei n. 195, de 24-2-1967, veio a regulamentar a matéria em seus 20 artigos.

Definição. E geralmente aceita a de Brlac Pinto: "pagamento obrigatório, decretado exclusivamente ou concorrentemente pelo Município, pelo Estado e pela União, em razão da valorização produzida em imóvel do contribuinte, por obra pública, realizada após sua audiência, e cujo montante não pode ultrapassar nem o custo da obra nem o valor do benefício."

Natureza jurídica. Eis aí matéria das mais controvertidas.

Encarece o prof. Adolfo Giaquinto que alguns escritores tentaram procurar o fundamento e a justificação do instituto no direito privado, fazendo-o entrar no conceito da gestão de negócios ou na proibição do enriquecimento inderido.

Refuta, com razão, essas concepções: as entidades que provêm à execução das obras produtoras de contribuição não tencionam cumprir um negotium alienum, nem a vantagem que delas retira o particular se pode dizer adquirida de modo não conforme ao direito.

Demonstra por sua vez Alberto Deodato que correm diferenças entre a contribuição de melhoria e as outras duas grandes categorias tributárias: não é uma taxa, nem um impôsto. É um tributo especial, tendo afinidades maiores com a primeira.

José Geraldo Ataliba Nogueira passa em resenha as opiniões mais credenciadas: para EıNAudi, não é mais do que forma de remuneração parcial do custo de obra desenvolvida no interêsse comum.

Para o prof. Dalton, é expediente destinado a assegurar ao erário público parte da valorização alcançada pela propriedade, independentemente do ato do proprietário.

Giannini a considera tributo especial; Seligman define-a como "contribuição obrigatória, percebida na proporção de benefícios especiais recebidos, para cobrir custo de 
melhoria especifica da propriedade, trazida por obra empreendida no interêsse público."

Passando para a doutrina pátria, encarece que em flagrante discordância com Bilac Pinto, que eleva a contribuição de melhoria a tertium genus, estão as autoridades de Carvalho Pinto, O. A. Bandeira de Melo, Teotônio Monteiro de Barros, J. H. Meirelles Teixeira, Pontes de Miranda, Francisco Campos, Temístocles Cavalcánti, que não vêm razões substanciais para distinguir contribuições especiais de taxas. A contribuição de melhoria seria uma espécie de sub-taxa.

Esposam a tese da tricotomia, além de Bilac Pinto, Gomes de Sousa, Aliomar Baleeiro, Rui Barbosa Nogueira e outros.

Podemos, com Gerldo Ataliba, concluir que "o importante é salientar o relêvo dado pela doutrina a essa entidade tributária e assinalar o explícito ou implícito reconhecimento de suas virtudes e especiais características, que lhe justificam o sucesso e a adesão que vai grangeando à medida em que é divulgada e conhecida, em que pese o complexo de dificuldades que cercam sua aplicação."

Fundamento. Deduz Adolfo Giaquinto da exposição de motivos de Pisanelli que o instituto encaixa-se no conceito da desapropriação e, surgindo sôbre o terreno do interêsse público, tem finalidades nìtidamente publicísticas, embora se reflita sôbre os patrimônios particulares.

A mesma exigência de justiça distributiva, que constitui o fundamento do instituto da desapropriação por utilidade pública (isto é, que quem se beneficia de obra pública deve também sustentar as despesas e portanto oferecer adequada indenização aos bens particulares que sejam sacrificados pela realização daquelas finalidades), é colocada na base da imposição da contribuição.

Neste último setor, porém, o princípio atua de forma quasi antitética, uma vez que, enquanto na desapropriação por utilidade pública a coletividade retira vantagem da obra pública e conseqüentemente corresponde ao titular do 
bem sacrificado a indenização adequada, no setor da contribuição o bem singular retira vantagem da obra pública e por isso concorre à despesa desta.

Por outras palavras, com a contribuição objetiva-se que o enriquecimento, que se verificou no patrimônio particular em conseqüência da obra pública, volta, ao menos em parte, à coletividade que a expensas próprias realizou a obra e produziu o enriquecimento: atua-se, assim, uma forma de concurso obrigatório dos particulares na despesa, concurso que em via principal e decisiva é medido não pela entidade desta despesa, mas pela vantagem alcançada pelo bem particular.

\section{Parte II}

\section{Aspectos principais do} decreto-lei 195, de 24-2-1967

Fato gerador e finalidade da contribuição de melhoria. Inscrevendo-se rigorosamente dentro dos postulados que acabamos de enunciar, dispõe o art. $1 .^{\circ}$ : "A contribuição de melhoria, prevista na Constituição Federal, tem como fato gerador o acréscimo do valor do imóvel localizado nas áreas beneficiadas direta ou indiretamente por obras públicas."

Como, porém, conceituar êsse acréscimo?

Considera Adolfo Giapuinto incremento de valor qualquer espécie de vantagem suscetível de avaliação pecuniária, levando-se em conta o valor de mercado do imóvel, ao preço que poderia ser obtido numa livre compra e venda.

"O aumento de luz e de apresentação de um prédio, a mais ampla e cômoda circulação, as comunicações mais fáceis e rápidas, a cessação de ônus e de servidões, o melhoramento das condições higiênicas, a possibilidade de destinação de um imóvel a usos mais rendosos são elementos dêste maior valor..." 
Do texto da lei resulta que o acréscimo deve resultar, de modo direto ou indireto, mas exclusivo, da realização de obras públicas.

Tem pois razão o mesmo autor quando observa não terem relêvo, para êsse fim, os aumentos de valor que decorrem de causas diversas, como os fenômenos monetários, as transformações $\mathrm{e}$ as melhores utilizações do imóvel feitas pelo proprietário nem os outros determinados por causas gerais e complexas, como por exemplo, a maior importância e desenvolvimento assumido por uma cidade por ter sido elevada a capital de estado, pela instalação de um instituto superior de estudos. Mesmo quando estas causas de caráter geral se relacionem com o cumprimento de obras públicas, não se pode dizer que o incremento decorra de modo imediato e específico da obra pública, porque êle provêm, ao invés, do conjunto das transformaêões de vida e de ambiente de que aquela obra constitui sòmente o meio ou o complemento.

Quanto à finalidade da contribuição de melhoria é indicada no art. $3 .^{\circ}$ : destina-se a fazer face ao custo das obras públicas.

Obras que dão margem à valorização de imóveis de propriedade privada. O decreto-lei n. 195, de 24-2-1967, art. $2 .^{\circ}$, com critério análogo ao já seguido pela anterior Lei n. 854, de 10-10-1949, é minucioso na especificação, que compreende nada menos de oito itens.

Merecem ser lançados, entre inúmeros outros casos: abertura, alargamento, pavimentação, iluminação, arborização, esgôtos pluviais, parques, campos de desportos, pontes, túneis, viadutos, sistemas de trânsito rápido, abastecimento de água potável, esgôto, instalações de redes elétricas, telefônicas, suprimento de gás, funiculares, ascensores, proteção contra sêcas, inundações, drenagens, desobstrução de barras, portos e canais, construção, pavimentação e melhoramentos de estradas de rodagem, etc.

Se considerarmos, aduz Aliomar Baleerro, que a administração pública só autoriza a abertura de novas vias 
públicas se a emprêsa loteadora dos terrenos, introduz pavimentação, terraplenagem, coletores, etc., incorporando o preço dessas acessões, compreenderemos quanto se locupletam às expensas de todos os contribuintes, os proprietários de prédios, em zonas cuja urbanização vem a ser feita pela própria autoridade pública.

"Daí a conseqüência: se o proprietário não concorreu para as obras públicas dos logradouros onde está situado o imóvel e, afinal, o ônus das mesmas veio a recair sôbre a administração, esta poderá indenizar-se, restabelecendo a igualdade entre todos os titulares de terrenos. Outra solução conduziria à iniquidade insuportável de serem uns sobrecarregados do custo de obras, que lhes interessam e também ao público, ao passo que outros, sem o mais mínimo esfôrço ou investimento, receberiam o presente de obras idênticas realizadas pelos cofres públicos."

Será taxativa a enumeração?

Sem dúvida. Mas, como consigna o mesmo autor, o rol, conquanto limitativo, abrange qualquer obra direta ou indiretamente vinculada aos fins ou aos resultados mencionados. Pouco importa, por exemplo, que uma obra seja concebida e realizada para um fim não indicado nesse dispositivo, desde que dela resulte um efeito nêle incluído. $O$ importante, para aplicação da lei, é que a obra classificável num dos incisos haja aumentado o valor do prédio.

Tenha-se todavia presente a advertência de José GEraldo Ataliba Nogueira: objeto da tributação é a mais valia e não o bem estar trazido pela obra, ou o confôrto de que clesfruta o cidadão, ou o gôzo dos benefícios dela decorrentes, ou qualquer outra coisa que não a repercussão econômica benéfica.

"Com efeito, pode acontecer - e muitas vêzes acontece - que a obra pública traga maior confôrto a um imóvel ou lhe abra vista para um panorama esplêndido, tornando-o mais agradável; mesmo assim não caberá a contribuição de melhoria se não houver valorização. Pelo contrário, se a obra vem tornar desagradável o local ou lhe 
retíra a vista, o sossêgo ou o bem estar e, não obstante lhe traz valorização, será exigível a contribuição de melhoria de pleno direito."

Quem pode exigir e como pode ser exigida a contribuição de melhoria. Sòmente a União, os Estados, o Distrito Federal e os Municípios, segundo se deduz do art. $3^{\circ}$ da lei, podem cobrar a contribuição de melhoria.

E o art. 13 acrescenta que a cobrança resultante de obras executadas pela União, situadas em áreas urbanas de um único Município, poderá ser efetuada pelo órgão arrecadador municipal, em convênio com o órgão federal que houver realizado as referidas obras.

Os $\S \S 6 .^{\circ}$ e $7 .^{\circ}$ do art. 12 do Decreto-lei 195 regulamentam o lançamento e a arrecadação da contribuição mediante convênio, prevendo delegue a União aos Estados, Distrito Federal e Municípios essas incumbências.

Admite-se, sem dificuldade, a exigência, pela União, da contribuição devida pelas demais entidades de direito público interno.

Poderá, no entanto, ocorrer a hipótese inversa?

Em José Geraldo Ataliba Nogueira colhe-se a observação de que, imputando a Constituição as mais valias a quem empreendeu a obra, outorga-lhe faculdade, que pode ser exercida ou não, discricionàriamente, segundo critérios de conveniência e oportunidade.

"Logo, quando o município, p. ex., vai tributar a valorização imobiliária que beneficiou próprio federal, não o estará submetendo a constrangimento ou exercendo poder de soberano sôbre súdito. Está simplesmente exercendo faculdade incondicionada que lhe foi assegurada pela Carta Magna...

"Negar a possibilidade de exigirem-se, reciprocamente, contribuição de melhoria União, estados e municípios e admitir, concomitantemente, possam beneficiar-se da dedução na indenização por expropriação, das valorizações, é absurdo! 0 mesmo com relação à desapropriação por zona. Enfim, a conclusão só pode ser uma: ou se reconhece que 
as mais valias imobiliárias foram, pela Constituição, imputadas aos entes empreendedores das obras, e se admite o recurso a qualquer instrumento que assegure a efetivação dessa imputação, na medida da lei, ou se criam restrições ilógicas e injustificadas a isso."

Mas a verdade é que o decreto-lei n. 195 só admite a cobrança dos proprietários de imóveis do domínio privado (art. 3. ${ }^{\circ}$, parágrafo $3 .^{\circ}$ ).

Quanto ao cálculo da taxa de melhoria, de duas formas poderá orientar-se o legislador: levando em conta o acréscimo de valor do imóvel atingido pela contribuição, ou considerando o montante dispendido para a realização do serviço.

Adotando "como critério o benefício resultante da obra, calculado através de índices cadastrais das respectivas zonas de influência", o art. $3 .^{\circ}$ do Decreto-lei n. 195 optou pelo primeiro sistema.

$\mathrm{E}$ os parágrafos seguintes indicam que a apuração da contribuição de melhoria, a ser cobrada exclusivamente dos proprietários de imóveis do domínio privado, far-se-á atendendo a fatores relativos ao valor do imóvel, rateando proporcionalmente o custo parcial ou total, entre todos os imóveis incluídos nas respectivas zonas de influência.

Como se apura o custo das obras. O problema é de importância fundamental, não sòmente porque a contribuição de melhoria destina-se exatamente a "fazer face ao custo das obras públicas" (art. $3^{\circ}$ ); não apenas porque a sua determinação deve ser feita rateando-se, proporcionalmente, o custo entre todos os imóveis incluídos nas respectivas zonas de influência (art. $3 .^{\circ}, \S 2 .^{\circ}$ ), como ainda porque, nos têrmos do art. $4 .^{\circ}$, o custo das obras marca o limite da cobrança da contribuição de melhoria.

Semelhante apuração, ensina Aliomar Baleeiro deve ser feita, já para que se garanta ao contribuinte a certeza de que não é tributado acima do custo, como proíbe a Constituição, mas também porque entre no cálculo de valorização. 
Esse cálculo implica em um arbitramento à luz de tôdas as provas de direito, inclusive a presunção e os indícios. Mas essa presunção, como prova, cede à prova em contrário, que deverá ser feita pelo contribuinte ao impugnar a cota que, em rateio, lhe coube por qualquer critério de repartição.

Pagamento. Com relação ao pagamento, finalmente, contém o Decreto-lei 195, em seu art. 12, diversas normas importantes.

Antes de mais nada, a parcela anual de contribuição não deve exceder a $3 \%$ do maior valor fiscal do imóvel, atualizado à época da cobrança.

O $\S 1^{\circ}$ autoriza descontos para pagamento à vista ou em prazos menores que o lançado. Acrescentam os $\S \S 2 .^{\circ}$ e $3 .^{\circ}$ que as prestações serão corrigidas monetàriamente, e que o atrazo no seu pagamento sujeitará o contribuinte à multa de mora de $12 \%$ ao ano.

O $4^{\circ} .^{\circ}$ prevê a eventualidade do contribuinte liquidar a contribuição de melhoria com títulos da dívida pública, emitidos especialmente para financiamento da obra pela qual foi lançado.

Essas, num rápido apanhado, as considerações que me pareceram mais oportunas a respeito da nova lei sôbre a contribuição de melhoria.

Trata-se, sem dúvida, de critério mais equânime até hoje lembrado para permitir à União, aos Estados e aos Municípios enfrentar os complexos problemas do financiamento de obras de interêsse coletivo, mediante uma distribuição dos encargos aos que delas mais venham a se beneficiar. 